\title{
أسلوب التعبير عن المنتظر في العهر القديم
}

أ.د. المتمرس مناف مهذي الموسوي

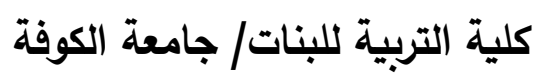

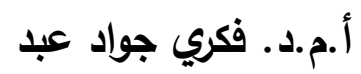

كلية الاراسات العليا/ جامعة الكوفة

الباحثة زبنة كاظم محسن

المقدمة:

تعرض العهد القديم إلى فكرة الانتظار والمنتظر وقد وردت نصوص كثيرة تشير إلى ذلك، وكان أسلوب الكناية هو المصطلح المعبر عن المنتظر كما سيتضح في المطالب اللاحقة، وتجدر الإشارة إلى أنّ التراث اليهودي قد عبّر عن هذه الفكرة وذكر للمنتظر صفات متعددة وحاول تطبيقها على شخصيات كثيرة كما تذكر المصادر التراثية والحديثة منها لكنها لم تتطبق تمام الانطباق فضلا عن عدم تحقق النبوءات التي وردت في الكتاب المقدّس، ومازالت هذه المواصفات إلى الآن غير متحققة فيما يصبو إليه اليهود على وفق النقاق

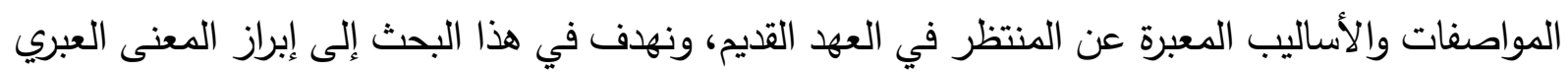

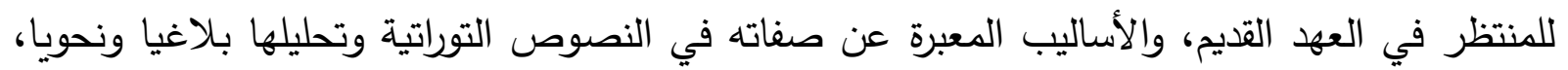
وسيعرض هذا البحث المطالب الآتية: أولا: المعنى العبري للمنتظر في اللغة العبرية. ثانيا: الوعد بالمنتظر في العهد القديم والبشارة به. ثالثا: أسلوب التعبير عن المنتظر في العهد القديم بذكر صفاته.

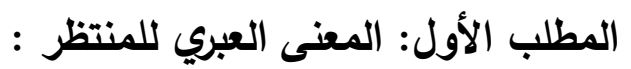
إنّ دلالة المنتظر في العبرية يأتي بمعنى: "المنقذ أو المخلص ففي اللغة العبرية أصله الفعل (ישاעה) بمعنى إنقاذ أو خلاص، وهي كلمة مشتقة من الفعل "ישلا" بمعنى أنقذ أو خلص. وتعنى الخلاص بمفهوم 
عام. والفعل الآخر هو(גאולה) بمعنى خلاص، من الفعل"גאל" بمعنى خلص أو أنقذ ومصدره (גאולה)

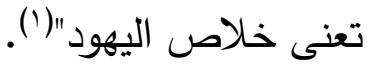

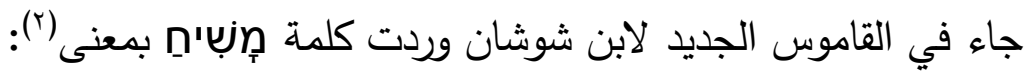

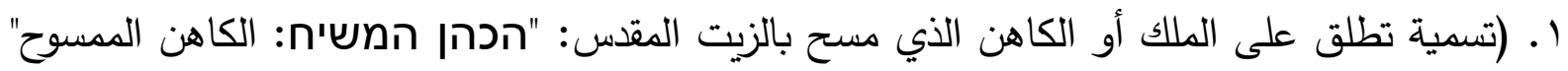
(ויקרא ד ג). "ויתן עז למלכו וירם קרן משיחו: وأعطي قوة لملكه ورفع كأس مخلصه" (שמואל א ב י). "אלו שני המשיחים: אחד משוח מלחמה، ואחד משוח למלך על ישראל: هؤلاء المخلصان: أحد ممسوح حرب، والآخر ممسوح لملك على إسرائيل" (פ0יקתא רבתי ל.).

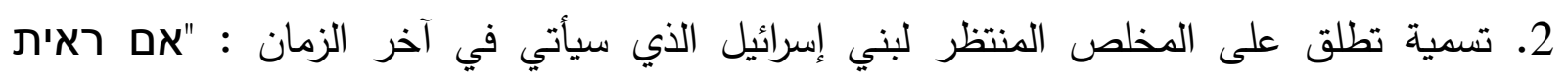
ספסליןמלאין בבליים מנחים בארץ ישראל...אם ראית 010 פרסי קשור בארץ ישראל צפה לרגליו של משיח: إذ رأيت مقاعد مليئة بابلية موضوعة في فلسطين.... إذا رأيت حصانًا فارسيًا مربوطًا في فلسطين - انظر لرجلي المخلص"(איכה רבה א، ממרום). ז. صفة ممسوح، معطر : "מגן שאול בלי משיח בשמן: درع شاؤول دون ممسوح بزيت"(שמואל ב ב א כא ((1)

ويذكر دافيد سغيف في قاموسه ، وكذلك ابن شوشان أنّ كلمة המשיח:

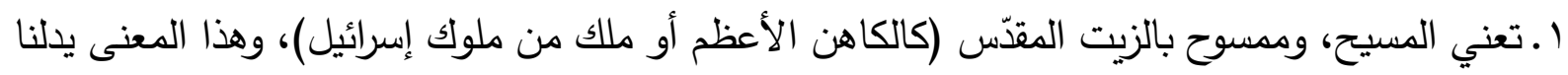

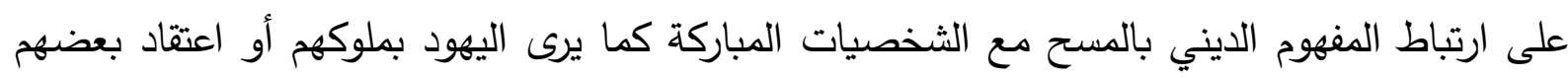

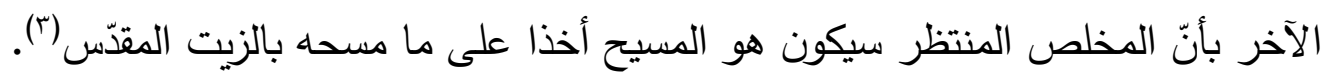
r. الممسوح بالزيت، المنقذ المنتظر ، المخلص (الذي سيأتي يوم القيامة لينقذ العالم من شروره حسب التئي التقاليد

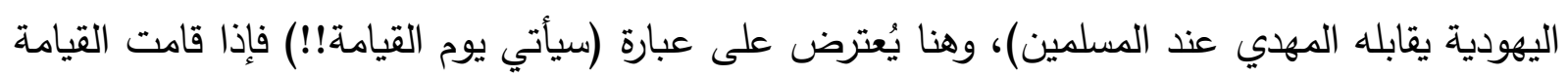

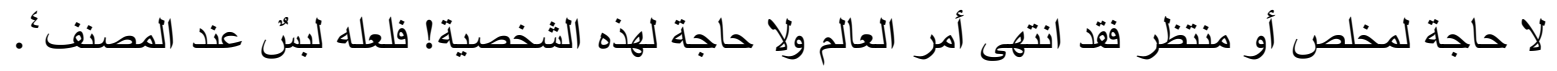


وأشار قوجمان إلى دلالة الفعل على المسح بالزيت ومجازا مسح الأرض أو قياسها بالخيط، وأما الاسم

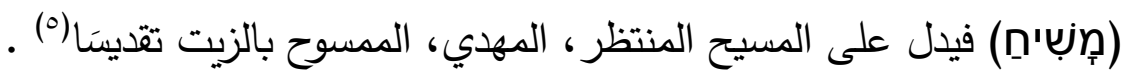

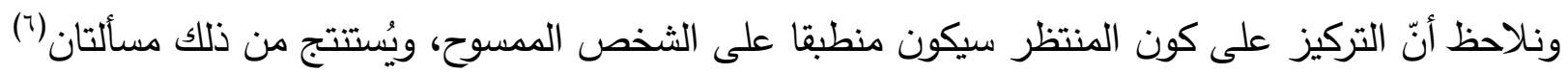

أولهما: أنّ عملية المسح هذه ليست لأهداف دينية فقط وإنما تتعلق بأهداف تطبيبية. ثانيهما: أنّ الدلالة العبرية للممسوح أو المسيح ليست مختصة بثخص معين، لأنّ النصوص في العهد القديم تثير إلى شخصيات متعددة قد مُسحت بأمر الله، كعلامة دالة عليهم كونهم سيؤدون وظيفة خاصة في المجتمع، شخصيات عليا كالأنبياء والملوك والأحبار . المطلب الثاني: الوعد بالمنتظر بالعها القديم والبثارة به: البشارة بالمنتظر في العهد القديم: نجد في النصوص التوراتية تبشر وتثير إلى المنتظر وخطاب الربّ له وأن يكون النسل منه مستمرا أبد

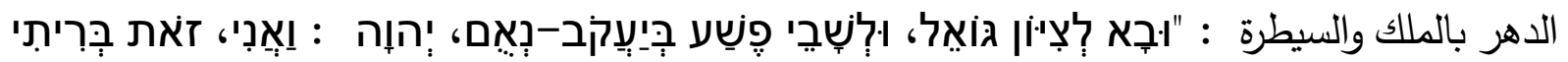

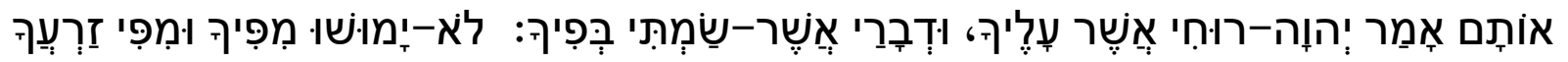

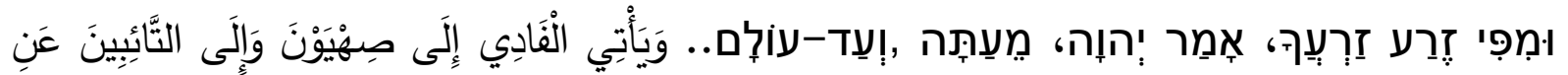

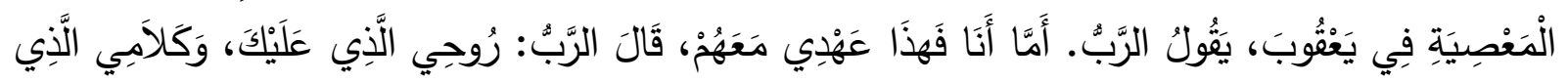

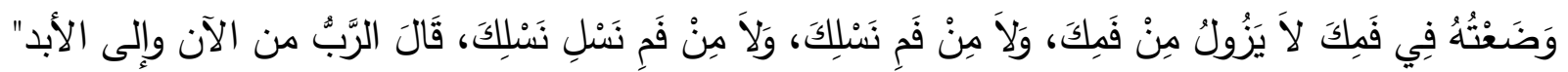

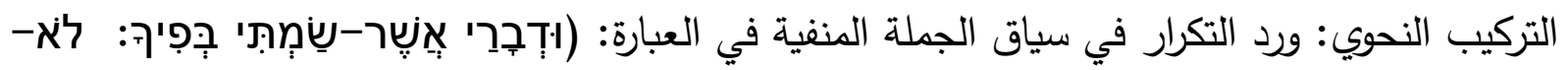

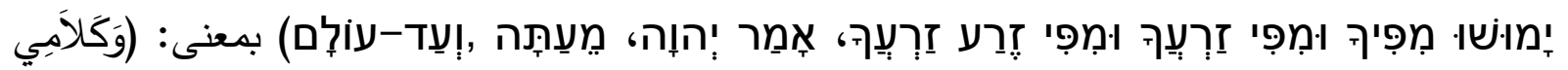

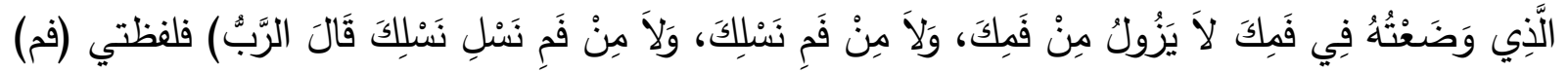

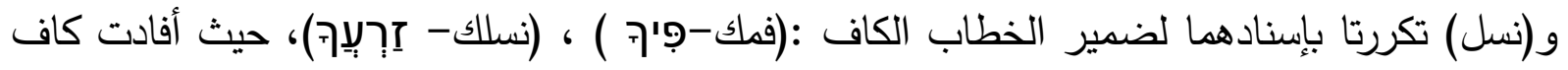


الخطاب الاختصاص ببقاء الملك والحكم لهذا النسل من سلالة يعقوب وداود وصولا للمنتظر الذي سيحكم

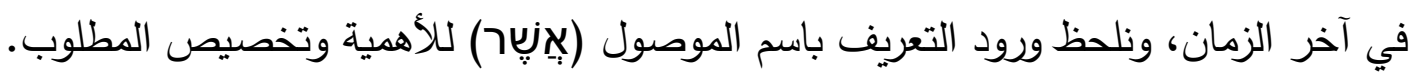
الأسلوب البلاغي: ورد الالتفات من الغيبة للحضور للتعبير عن المنتظر ووصفه النص هنا بالفادي وهو:

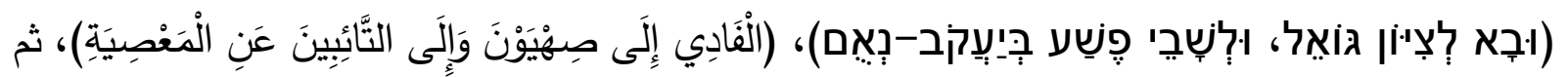
تحول إلى خطاب المنتظر بالفعل الذي وردت فيه الكناية عن القوة والحكم والسيطرة في نسل المنتظر وألّا

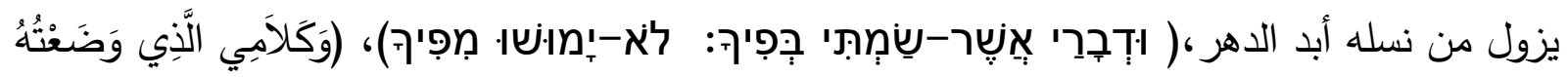

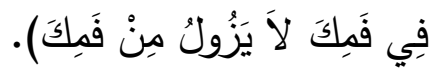

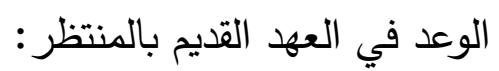
وردت نصوص كثيرة في العهد القديم بوعد الله لأنبيائه بإثبات النسل منهم وجعلهم أمما كثيرة واستمرار ذلك بهم إلى الأبد وهذا ما دلت عليه النصوص بما فيها من قرائن سياقية ولفظية وأساليب تعبيرية متنوعة فنجد وعد الله بإثبات نسل داود وتكررت في المزمور التاسع والثمانين إذ يقول:

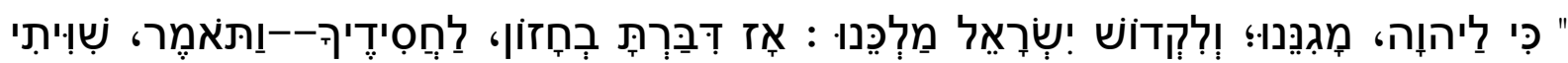

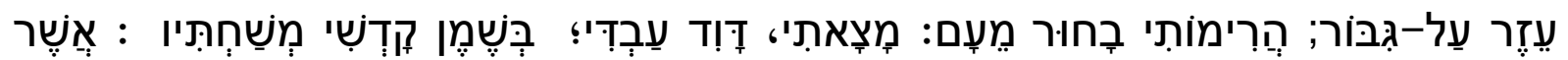

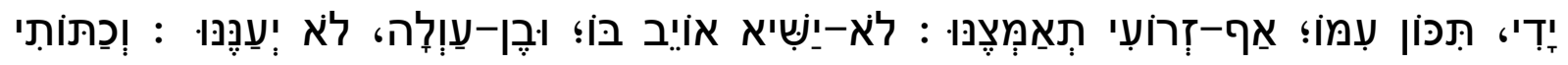

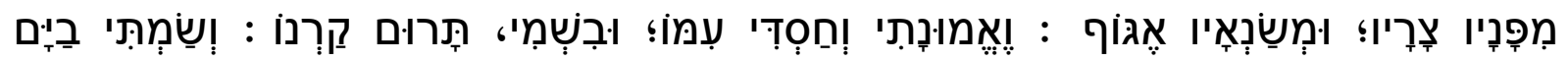

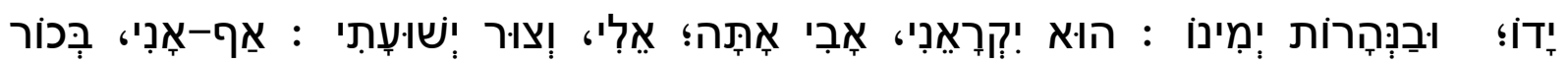

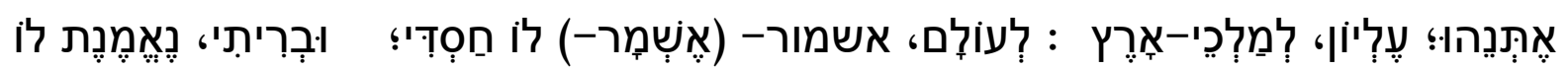

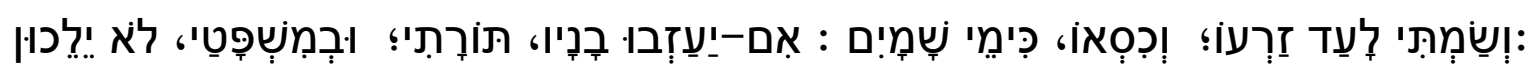

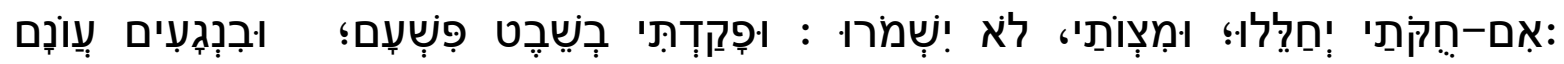

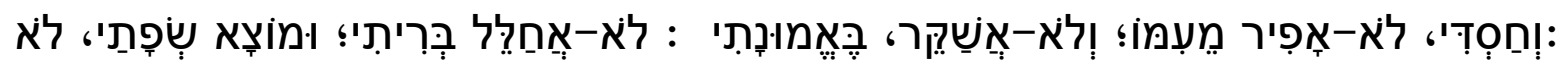

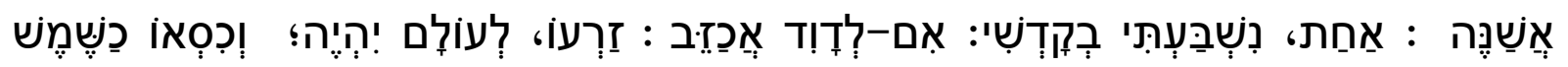




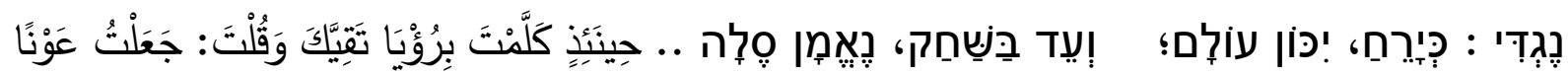

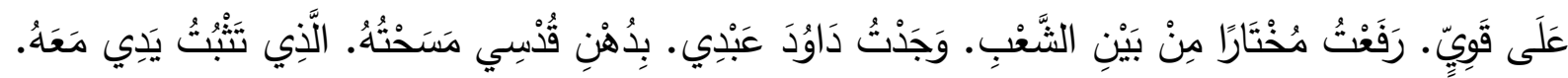

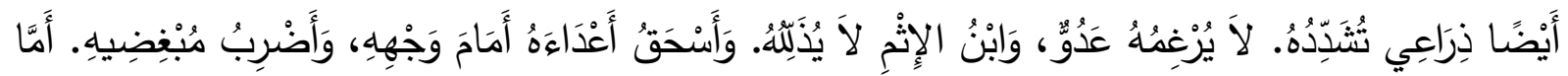

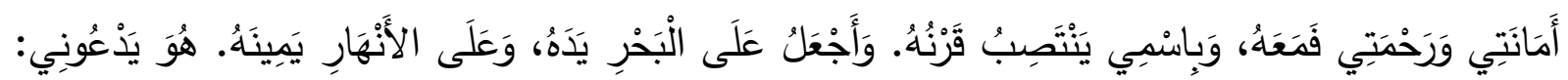

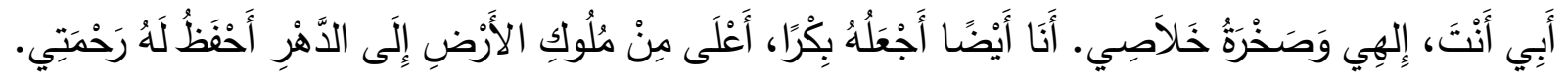

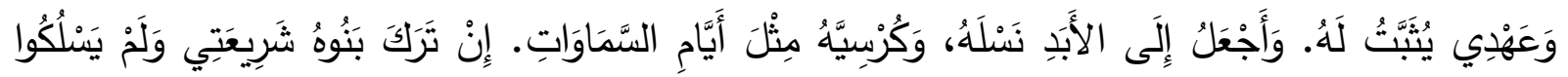

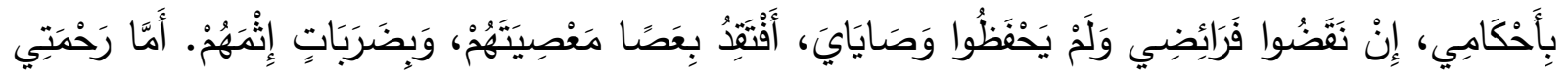

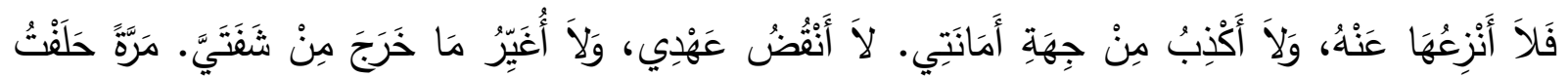

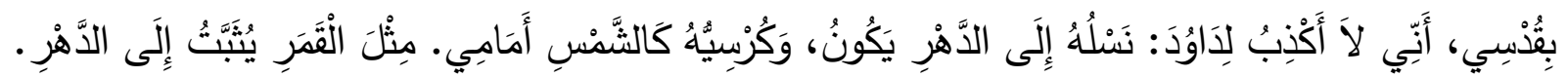

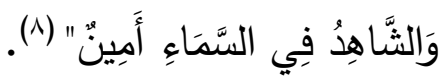

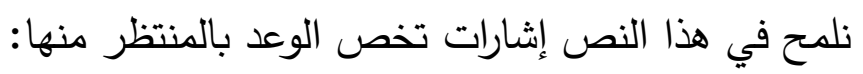

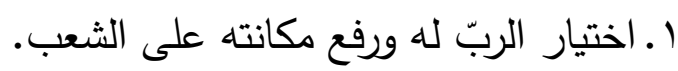
r. ذكر داود (ع) ونسبة الرب له بعبوديته وإعطائه الملك وهو ما تؤمن به اليهود بأن يكون المنتظر من نسله. r. إثبات قضية المسح والمباركة بالدهن وتقديس الممسوح.

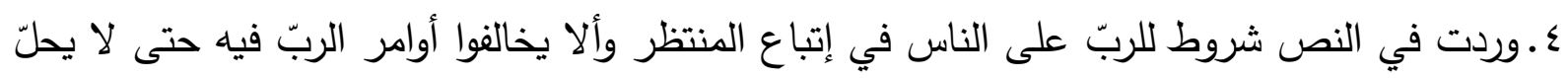
عليهم غضب الربّ ويكثف زيفهم. ه. الوعد بأن يكون النسل أبد الدهر للمنتظر، وأنّ هذا الأمر حتم تدلنا عليه سياق القرائن اللفظية الواردة في النص. التركيب النحوي: كثُرت في النص الجمل الفعلية لتعطي معنى الحدوث والتجدد راسمة المعاني المستقبلية التي سيحققها الربّ بالمنتظر، كما نوعت التراكيب النحوية حيث ورد النفي المراد منه إثبات ما عداه، كما 
يُلاحظ أنّ الجمل الاسمية جاءت بذكر توصيف المنتظر، وتكرر الفعل (ثبت) مرتين، (الَّنَي تَنْبُتُ يَدِي

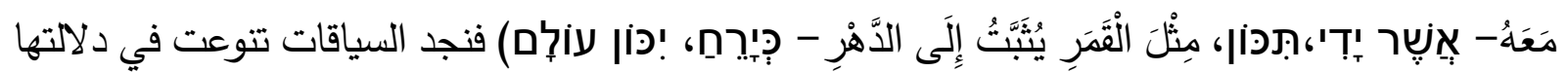
ففي الجملة الأولى ورد الفعل بصيغة المضارع للمخاطب المؤنث في حين كان للمخاطب المذكر في الجملة الثانية، والفاعل هو (القعر)، ('بجרِ) وقد جاء معناهما مجازا ، تكرر سياقات الجملة الثرطية وجوابها في

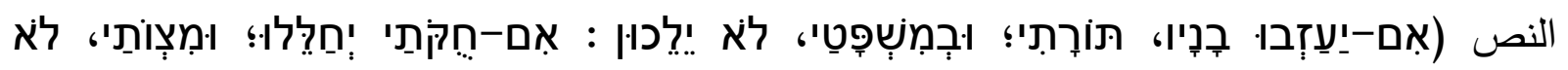

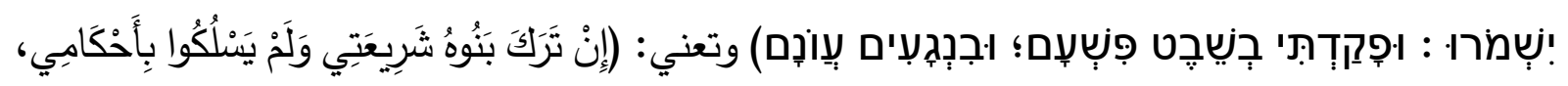

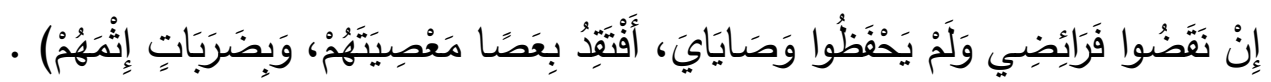

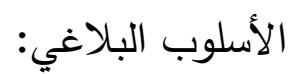

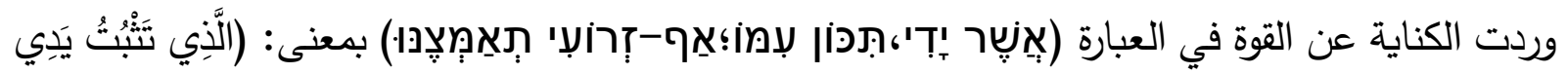

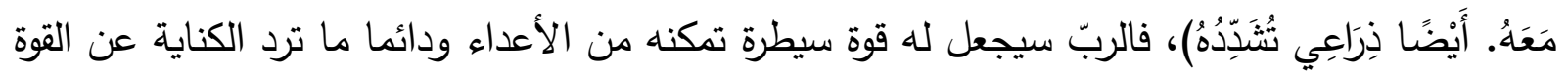

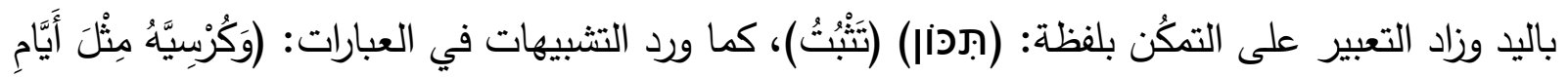

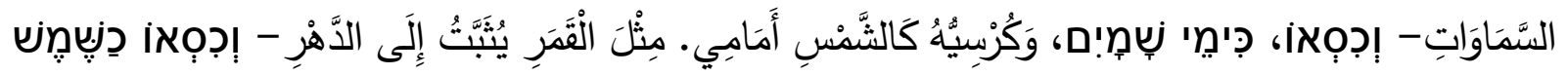

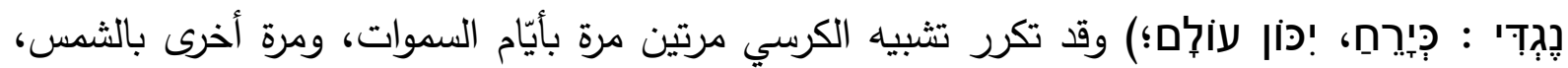

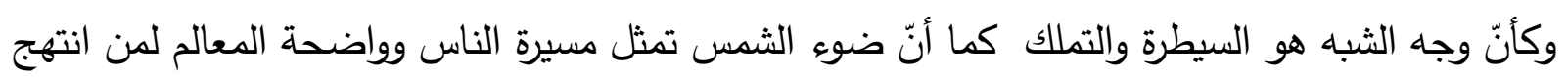
مسيرة المنتظر، وأمّا أيام السموات فهو يدل على سعة الملك وعظمته ورسم صورة لسطوة المنتظر وسيطرته. المطلب الثالث: أسلوب التعبير عن المنتظر في العهد القديم بذكر صفاته:

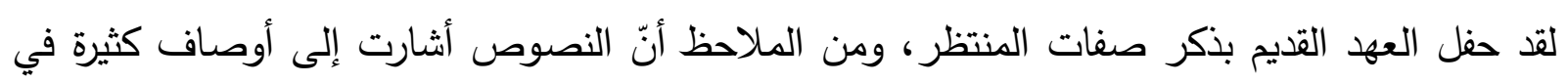

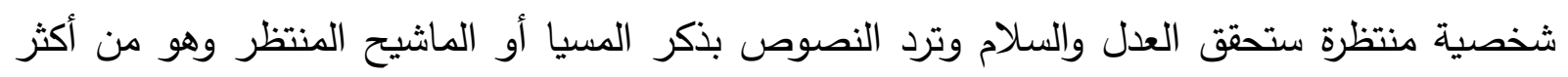

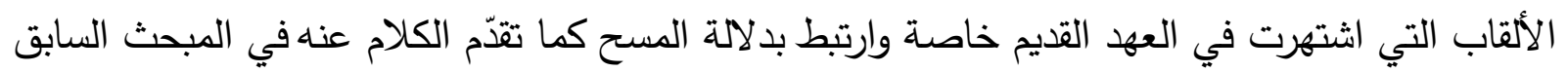
بمعنى المسح للمقدس والمبارك، وتنوعت الدلالات التي وردت للمسيا أو الماشيح، ويدل المسيا على الصيغة

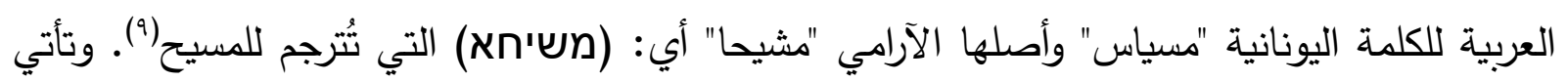


اللفظة مشكولة بالفتح البتاح تكون اسما خلاص، إنقاذ، عون، مساعدة، وإذا كانت اللفظة مشكولة بالقماص-

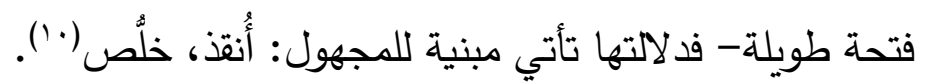
ومن الصفات التي سنعرض لها في هذا المبحث: ( ابن الإنسان، ابن الملك، العادل والمنصور، الوارث للأرض، جذع يسي، القائم، البقية، المنتقم).

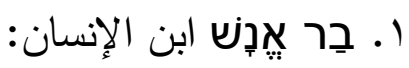
يأتي ذكر هذا اللفظ في العهدين القديم والجديد(')وأول ما ورد هذا اللقب في سفر دانيال، إذ جاء في الإصحاح السابع منه:

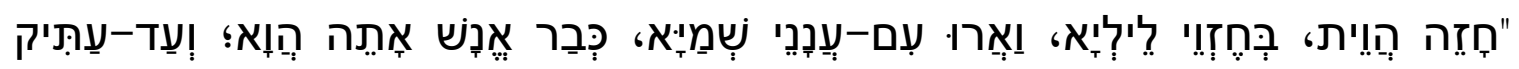

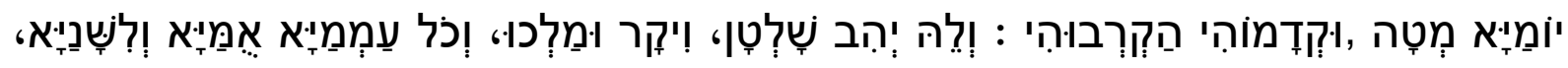

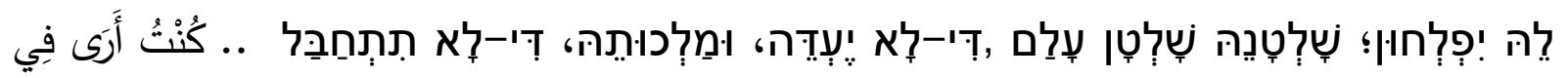

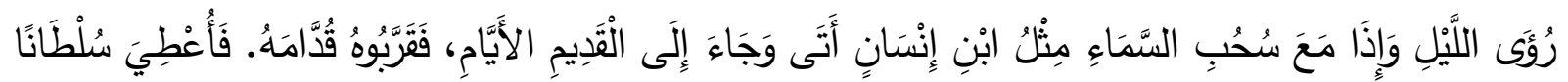

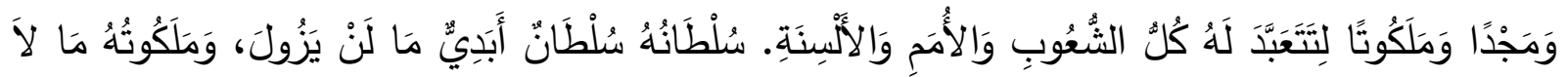

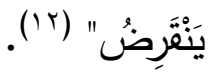

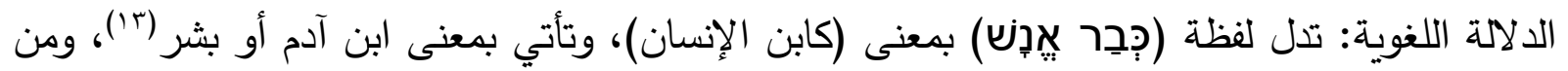

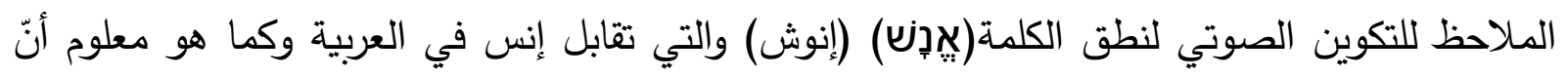
الإبدال يقع بين العربية والعبرية بحرف السين إذ تلفظ شينا في العبرية، والمفرد من هذه اللفظة للمذكر (بِن إنس) ونتيجة التطور اللغوي أُبدلت الياء نونا وتعود نون المفرد عند الجمع فتكون(بِرِّنسه) ومنه في العربية

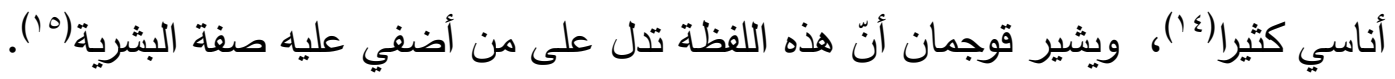

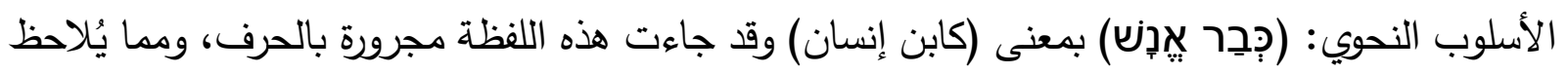
في النص ورود الصفة بلفظة (ابن) وهو أيضا صفة للموصوف بدلالة على اهتمام اللغات السامية بالنسب،

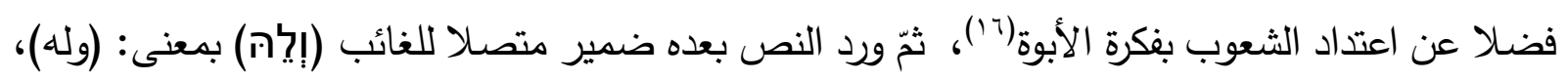


سبقه واو العطف، وجاء مجرورا بلام الجر وهو يدل على التخصيص والتمليك(`')، للمعرفة الواردة في الفقرة السابقة فعدل عن المعرف بالإضافة بالضمير الغائب، وجاء خبرا مقدما. والفعل (:بمد) ماضٍ مجرد معناه (وهب)، وهو فعل معتل الفاء جاء بصيغة الماضي.

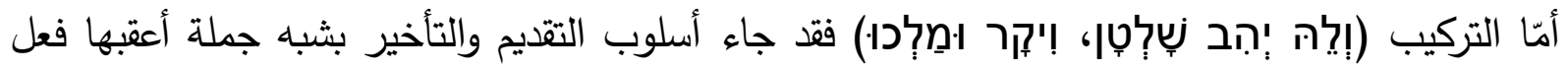
فمبتدأ مؤخر ، وهذه الجملة الاسمية جاءت واصفة لابن الإنسان ووردت الفقرات اللاحقة للتحدث عن ملكه وسلطانه، وتجدر الإشارة إلى أنّ العطف في اللغة العبرية جاء هنا بإشراك الاسمين في وظيفة المبتدأ

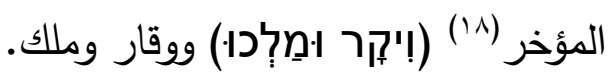
الأسلوب البلاغي: هذا ما يدلنا عليه تعبير التشبيه لهذا اللقب، كما أنّه جاء مجهولاً أيضا إذ يأتي التشبيه دالا عن معنى مقارب للمشبه به ولم يتحقق هذا في النص، وورد أسلوب الالتفات بين التعبيرين(جِجِِר

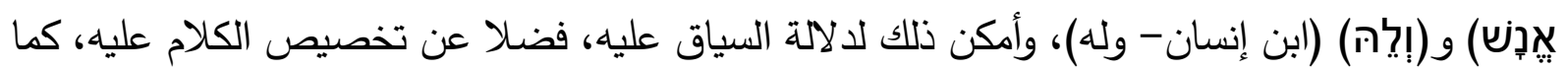

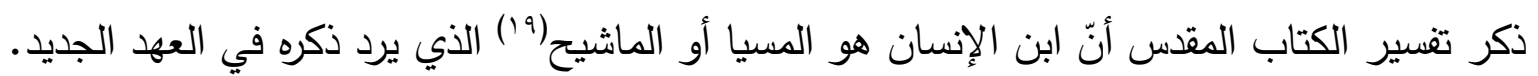

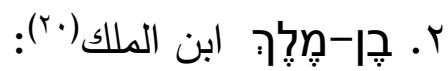

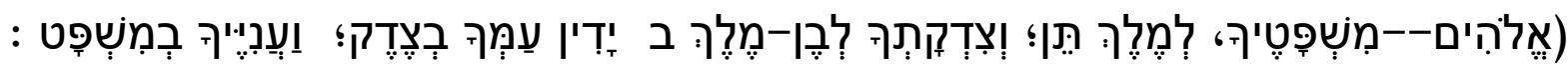

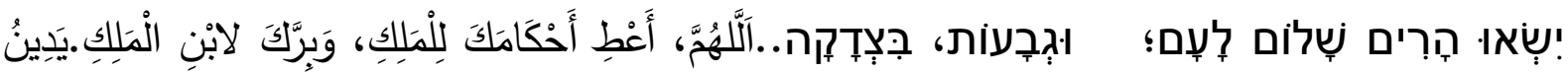

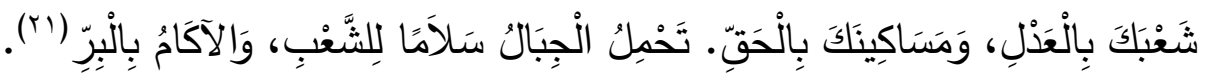

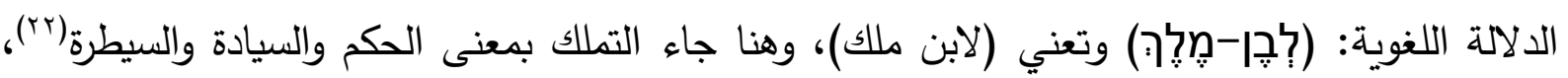
واُختلف في دلالة ابن الملك لتدل على شخصٍ بعينه- الملك وابن الملك- كونها تدل على شخصيتين معلومتين وهما: نبي الله داود (ع) وابنه الذي سيكون من نسله: ولا يمكن أن تكون دلالة النص عليهما من وجوه عدة(r) (r) أولا: ورد النص بأسلوب الدعاء والتذلل فلا يمكن أن يكون الداعي -داود- ويورد لفظتي الملك وابن الملك. 
ثانيا: وردت في سياق الفقرات اللاحقة أن يكون ملك الأمم أبد الدهر وعلى مرِ العصور والأجيال، وهذا لم

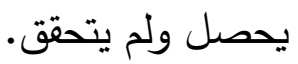

ثالثا: ورد النص بصيغة ضمير الغائب ومشيرا إلى عصر المستقبل بعد تحقق وجود ذلك الملك المنتظر.

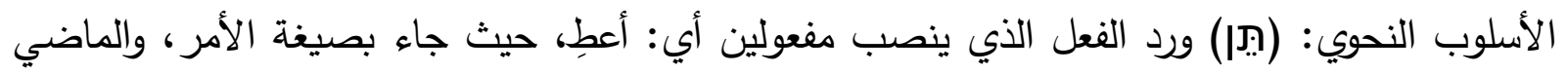

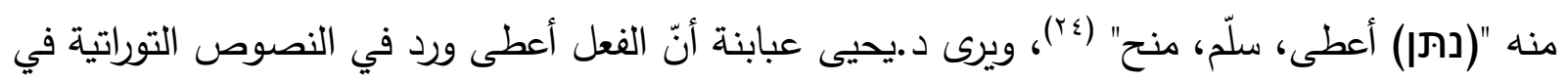
العبرية يأخذ مفعولين أحدهما شكلي غير مباشر والآخر مفعولا مباشرا من حيث الثكل والحركة كونه؛ كان

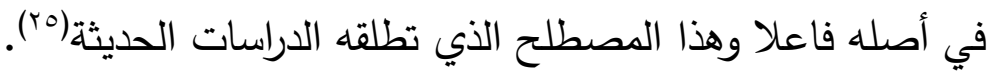
الأسلوب البلاغي: بدأ النص بالنداء مع حذف أداة النداء في لفظ (مِלهיه) ألوهيم وهو لفظ الجلالة، الذي يقابل في العربية (اللهمّ) وهي من المسائل الخلافية في اشتقاقها بين العربية والعبرية، وتدل هذه في ميمها المشددة على حذف حرف النداء الياء(r). كما ورد في النص أسلوب طلبي وهو الأمر وصيغة الفعل (هِرן) وجاء على صيغة أفعل- أعطِ، إذ إنّ

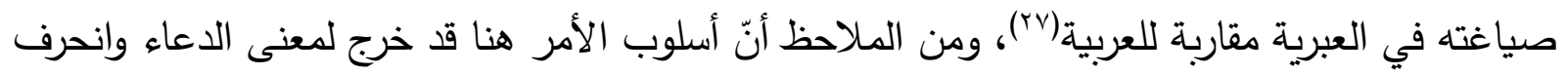
عن دلالته المباشرة بصدور الأمر ممن هو أقل رتبة إلى أعلى رتبة.

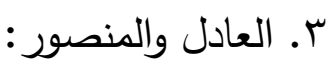

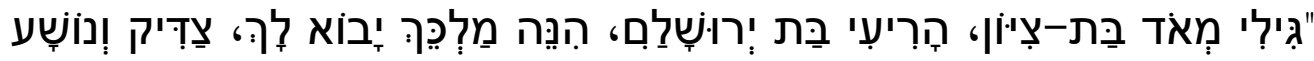

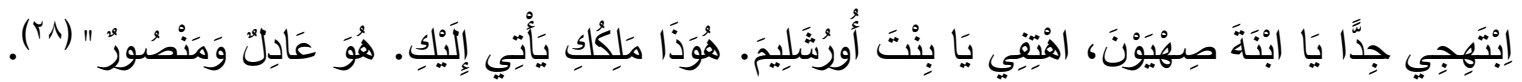

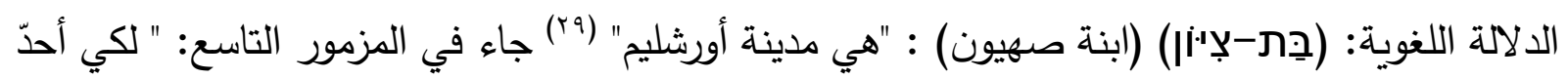
بكلّ تسابيحك في أبواب ابنة صهيون، مبتهجًا بخلاصك"( (r).

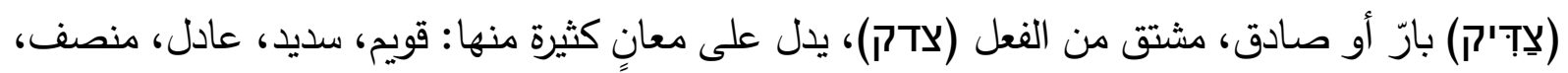

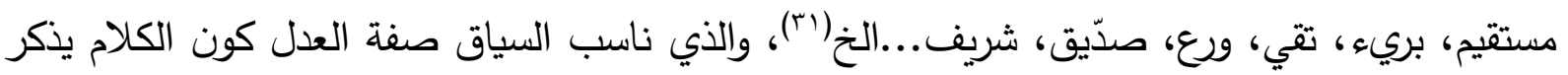
ملك. (دأنِِע) مخلِّص اسم فاعل مشتق من الفعل (ישע)، ومن المعلوم أنّ اسم الفاعل دلالته على المبالغة. 
الأسلوب النحوي: (جِجילי) فعل أمر بمعنى (ابتهجي)، والفعل (هِריلإ') بمعنى اهتفي بصيغة الأمر أيضا. وجاءا مسندين لياء المخاطبة (').

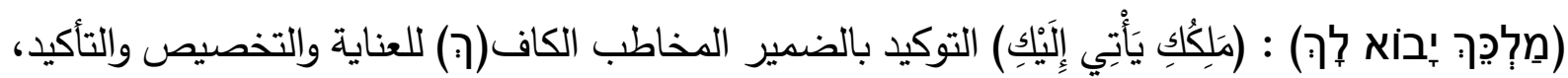
كما ورد التوكيد بلفظة (מְאד) وتعني (جدا). الأسلوب البلاغي: وردت أداة النداء مرتين لكنها محذوفة دلّ عليها السياق في النص فضلا بلا عن تصدر

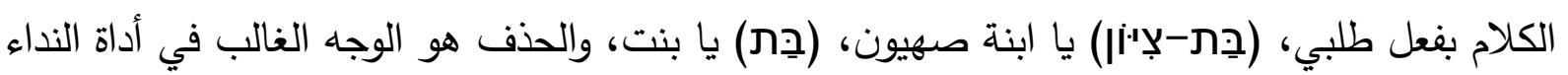
في اللغة العبرية. كما نلاحظ تكرار النداء مرتين لنفس المنادى المضاف باسمين دالين على منادى واحد وهذا التكرار حصل للتوكيد اللفظي (rr).

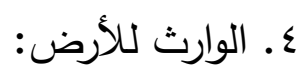

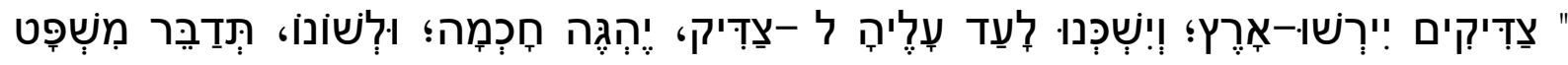

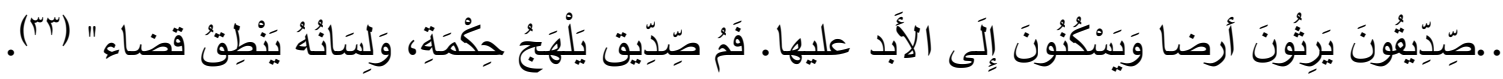

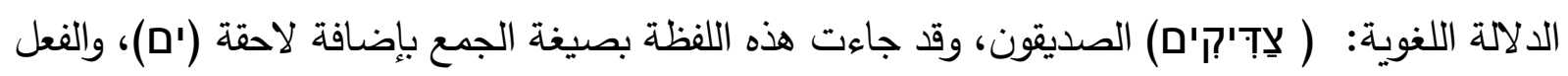

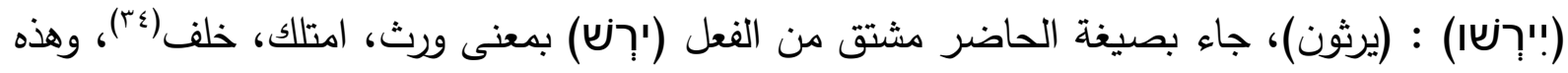
الوراثة جاءت بمعنى الحكم والسيطرة والسيادة، كما نجد في سياق الفقرات أن الوارث سيكون مخصنساء

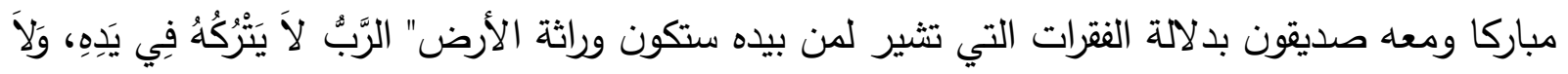

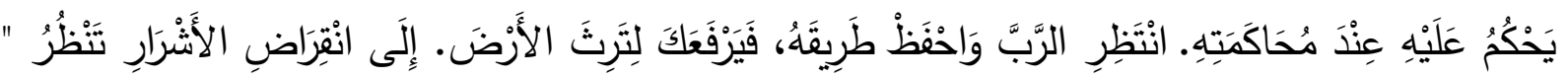

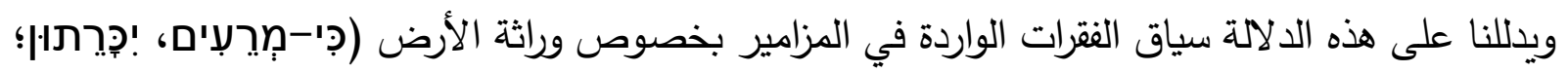

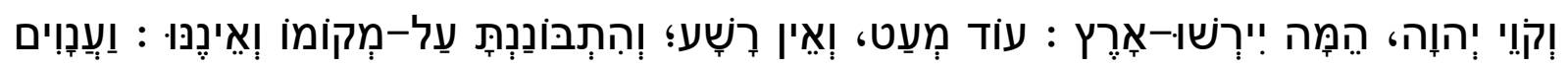
".

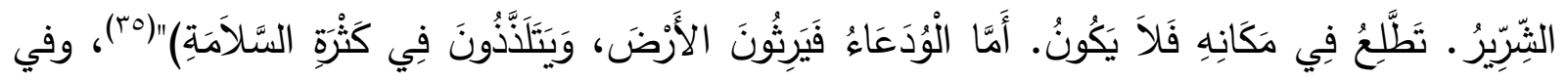




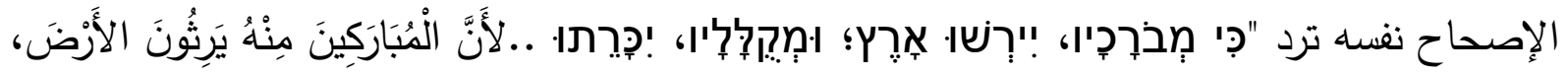

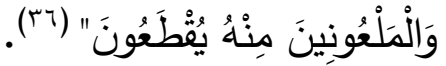

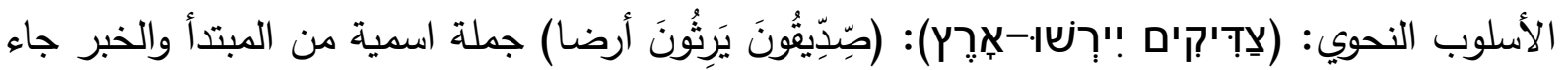
المبتدأ نكرة موصوفة، وهو من مسوغات الابتداء بالنكرة، كما وردت المطابقة بين المبتدأ وخبره بالجمع والتذكير ، والخبر (!ירְשוּ) جملة الفعلية نصب مفعول به وهو (אِרְץ)، كما نلاحظ أنّ الألفاظ جاءت نكرة لعدم تعيين هؤلاء الوارثين من جهة، ويحتمل أن تكون هذه الإثارة إلى كونهم سيكونون في زمان ونان متأخر ومستقبلي، فضلا عن الصفات الحميدة التي يحملونها.

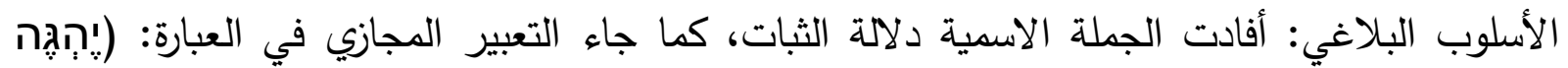

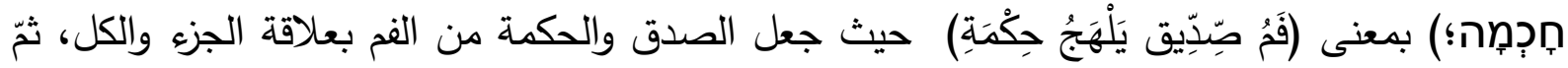

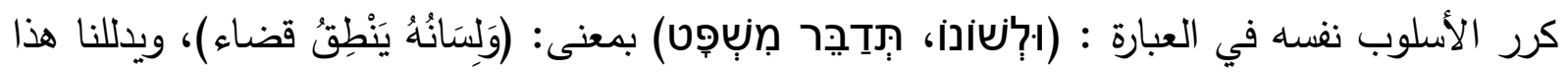
التعبير على الحكم والسيطرة التي سيتمتع بها المنتظر، فضلا عن الترتيب في العرض المختصر في هذا لها لهات

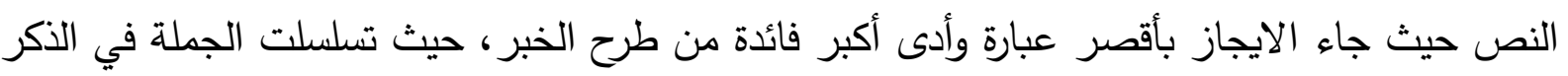

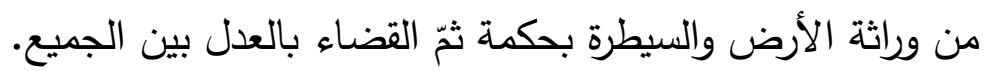

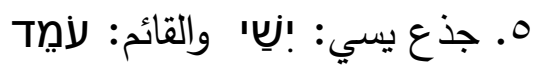

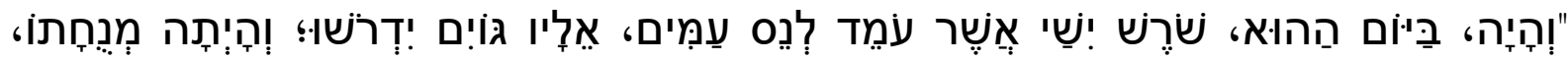

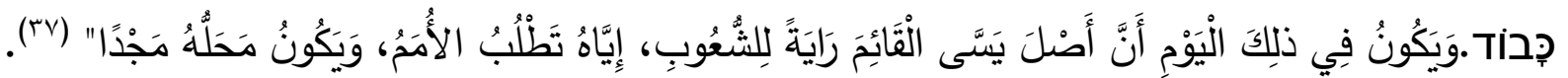
(هיָיה): (يكون)، فعل ماضٍ، مسبوق بواو القلب التي تدخل على الفعل الماضي فتيقلب معناه الى المستقبل

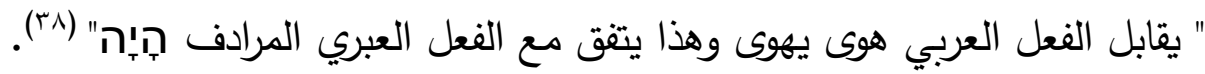

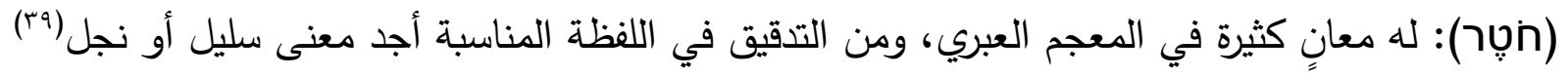
هو المناسب للسياق، وإن كانت الاستعارة مقبولة باختيار لفظة فرع وهي من إحدى إنى معانيه. 
(!نِשי) هذه اللفظة أختلف في دلالتها الاسمية أم الفعلية فنجد من يعدّه فعلا مضارعا بصيغة المستقبل بمعنى سيرفع، والذي أجده في أعلام الكتاب المقدس أن يسى هو اسم وهي لفظة عبرية تعني "الرجل، وهو الإه

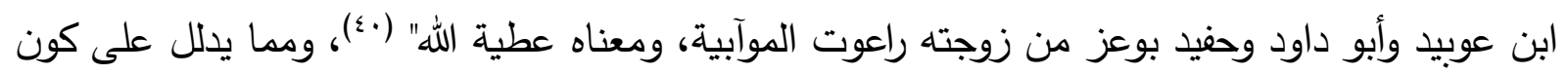

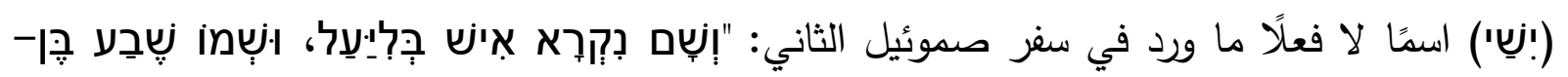

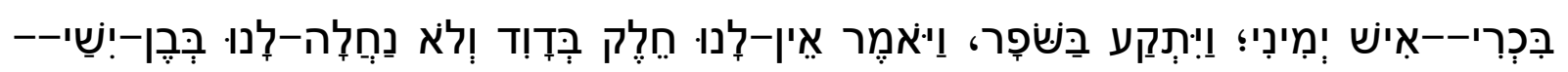

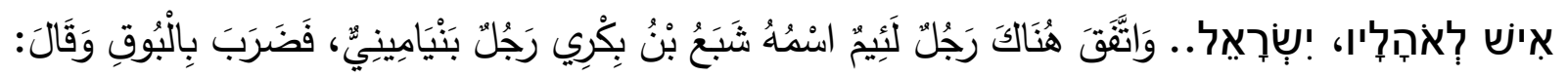

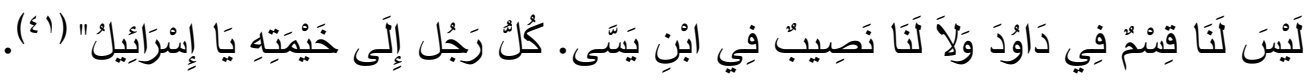

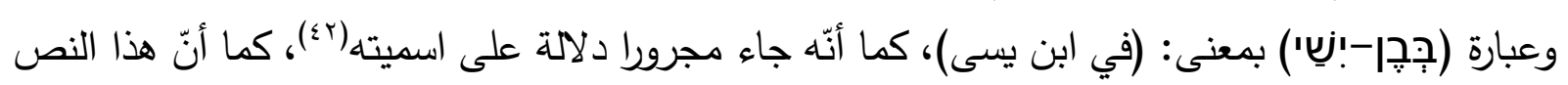

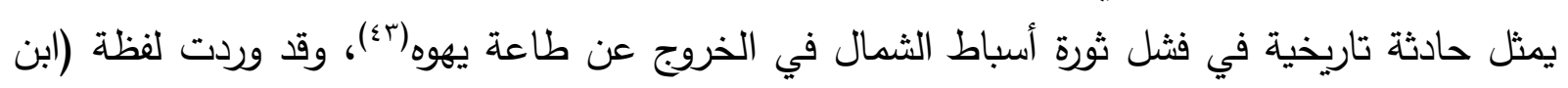

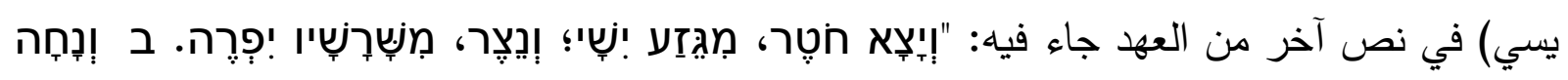

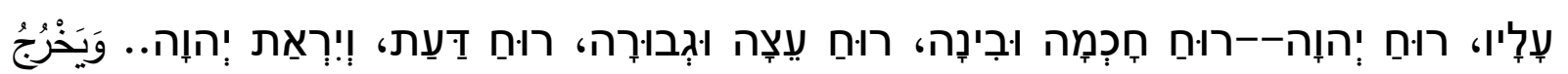

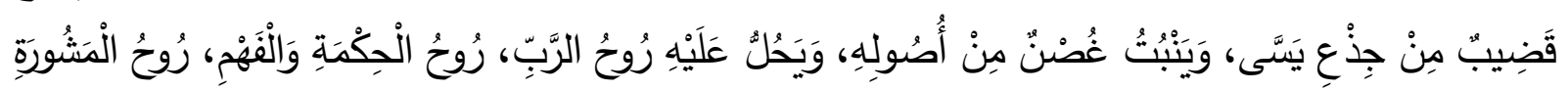

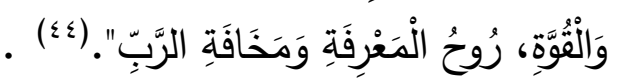
(مِשֶׁר) يأتي بصيغة اسم موصول بمعنى الذي وهو عام يدل على المذكر والمؤنت والجمع والمفردة، إلا

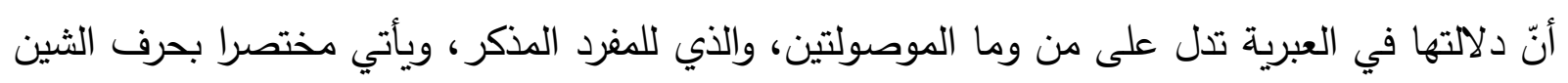

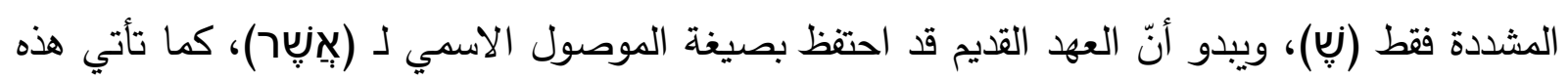

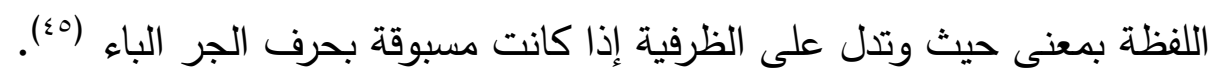
(لإِד) وهو اسم فاعل بمعنى (واقف أو موقف أو موقع)، ويرى د.محمد توفيق أنه "يقابل الفعل العربي

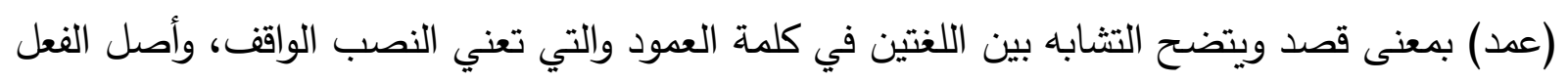

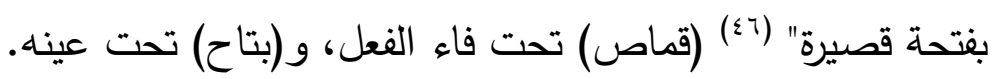
ד. بقية: (ְְשِאררית) 


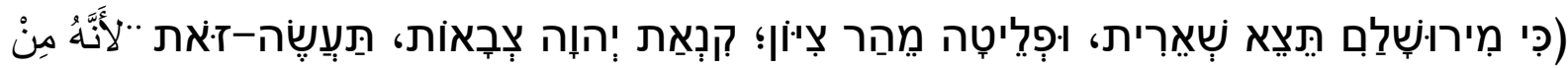

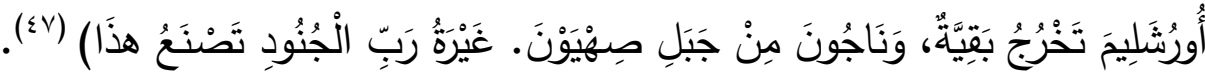

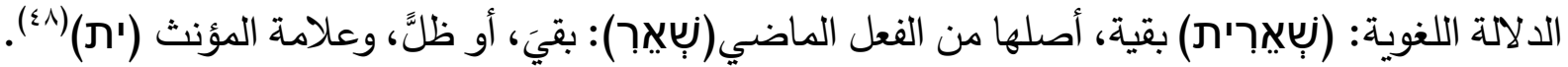

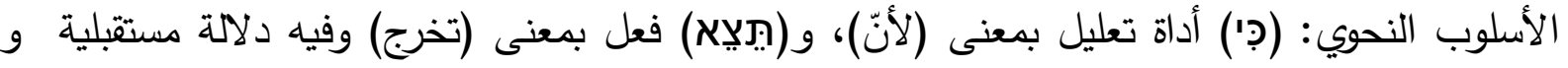

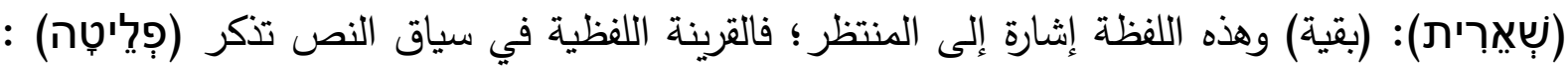
(ناجون)، وهذا بعد أحداث تكون قبل ظهور المنتظر ستكون هناك بقية يرسلها الربّ لتكون المخلصة لتلك الجماعات. V

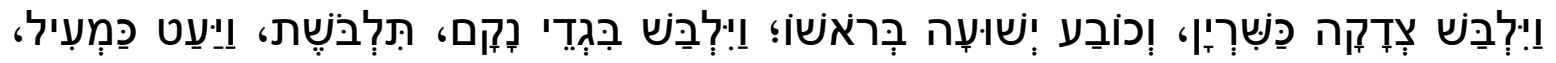

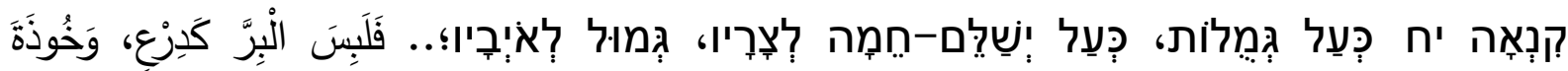

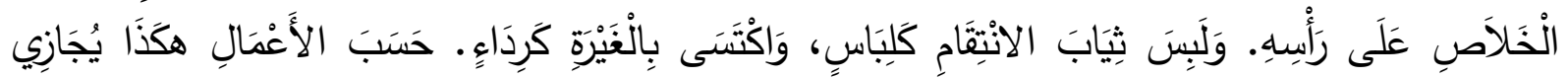

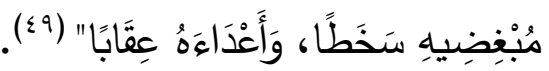
نلاحظ من هذا النص إثارات وهي على النحو الآتي: ا ـ ذكر النص شخصية سيكون الخلاص على يدها وموصوفة بصفي إسفات.

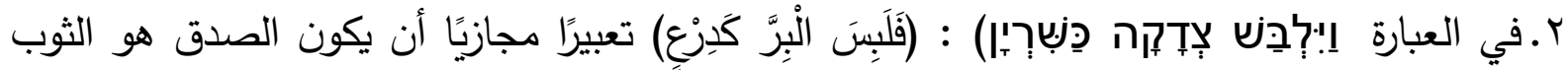

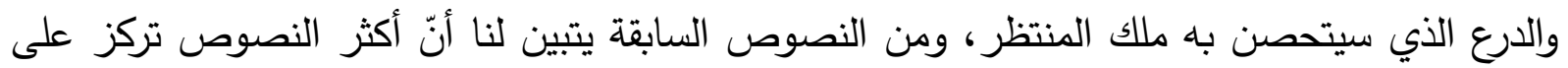
لفظة (بְדָקָה) بمعنى (البرّ والصدق)؛ كونها صفة مهمة في الحاكم من جهة، ويحتمل أن تكون هذه الصفة مفقودة في كثير من الثخصيات التي كانت من المؤمل أن تكون هي المنتظر نفسه ولم تحقق آمال اليهود بها، فضلا عن طول انتظار المنتظر يجعل سياق النص ينبئ بانتظار شخصية تتوافر فيها الصفات الحميذة التي تحظى بمقبولية لدى الجميع.

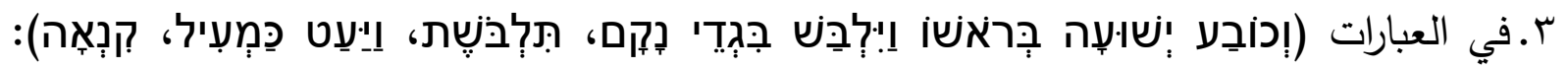




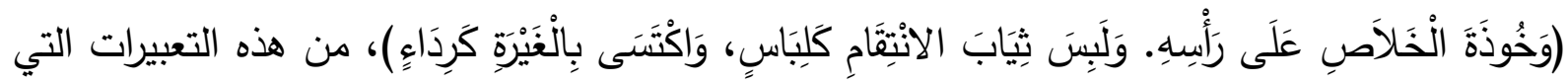
تصف المنتظر نلمح الكنايات البلاغية في وصفه، فخوذة الخلاص على على رأسه لتحكمه في الأمر ويحتمل أن تكون له علامة دالة أو يكون تعبير مجازي في حكته في التصرف والحكم، ثمّ انتقل النص بتكرار

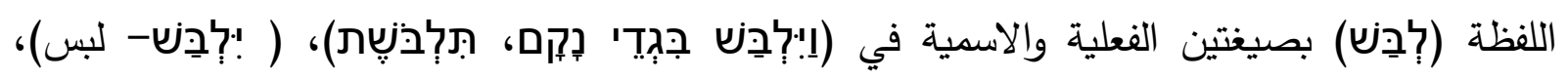

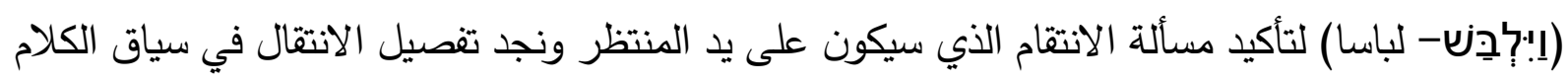

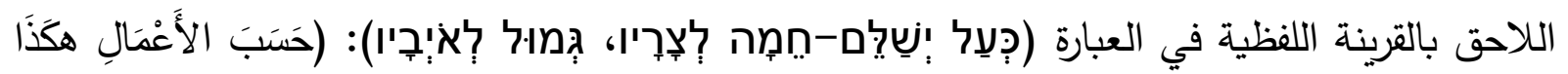

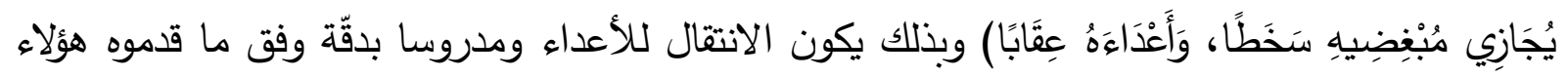
الجماعات من أعمال حسنة كانت أو سيئة. وهناك ألقاب وصفات كثيرة تشير إليها بعض المصادر : جاء في تفسير الكتاب المقدس لذكر بعض أوصاف ألفات

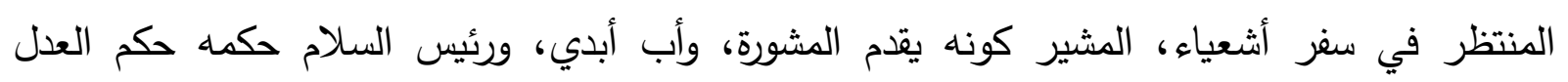

$$
\text { والسلام (.0.) }
$$

لقد وردت نصوص كثيرة في أسفار العهد القديم تُشير إلى المنتظر تحوي تعبيرات كثيرة ومتتوعة، ومن الأمور التي لاحظنا في العهد القديم ما يأتي:

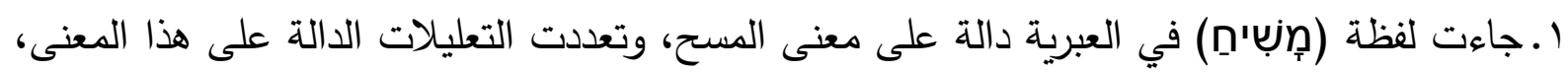
إلا أنّها محصورة في معنى التقديس والمباركة لذلك المدسوح. r. كثرة النصوص التي تذكر المنتظر وبنصوص واضحة البيان بل نجدها تذكر المنتظر وعصره وولادته وما يفعله في زمانه عند ظهوره من أحداث، وتارة نجد النصوص تلمح بذوبن بذكر المنتظر الموعود.

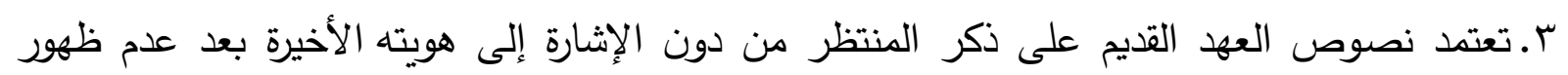
للمنتظر الموعود به في نصوص العهر القديم. ع. كثرة التفاصيل التي تذكر المنتظر بخصوص فوص ما يقوم به عند ظهوره. 
•. وردت الإشارة كون المنتظر سيكون ممسوحا حيث تضفي هذه الصفة لشخصية المنتظر دلالات خاصة في اللغة العبرية وأنها مختصة بالشخصيات العليا التي تمثل الأنبياء والرموز الدينية الكبيرة. 7 ـ تعدد ذكر الشخصية المنتظرة في العهد القديم والتي أشارت النصوص إليها . V. تشير النصوص إلى وقت الظهور وبتعبيرات مختلفة وتنبه على زمان المنتظر والتعبير عنه بـ "آخر

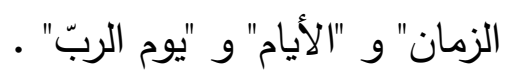
الهوامش:

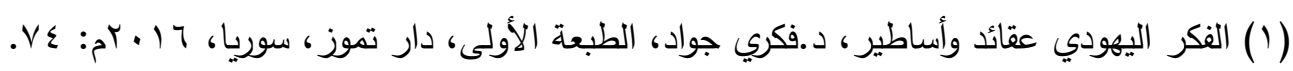
(ץ)אבן שושן، אברהם. המילון החדש. כרך שביעי. ירושלים. ישראל. 1971 עמ' 1555 ו1556. (ז)(שגיב، דוד. מילון עברי ערבי לשפה עברית בת זמננו. כרך ראשון. 1985. ירושלים. עמ' 1090. §()אברהם، אבן-שושן، המלון החדש، הוצאת קרית-0פר، ירושלים 1974، כרך רביע'، עמ' 1555

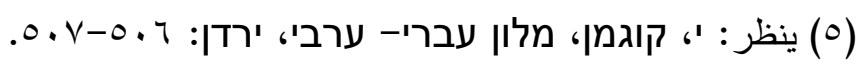

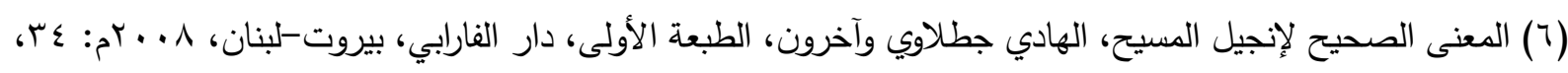

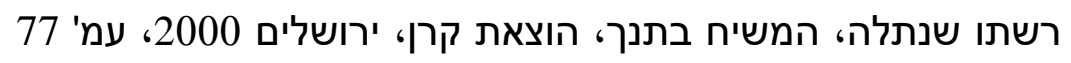

$$
\begin{aligned}
& \text { (Y) }
\end{aligned}
$$

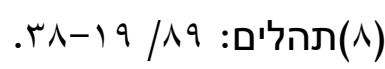

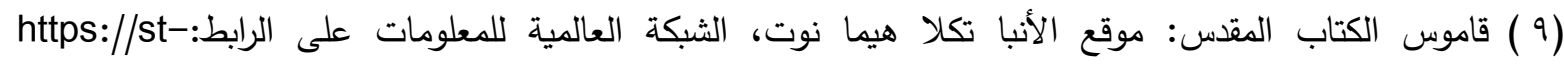
takla.org/Full-Free-Coptic-Books/FreeCopticBooks- . . r-Holy-Arabic-Bible-

.Dictionary/ $r \varepsilon \_M / M_{-} 10 \cdot . h t m l$

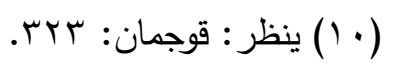
(1) إنّ الإشارة إلى ابن الإنسان من الألقاب المشهورة التي يوردها مفسرو العهد الجديد كونها تدل على المسيح عيسى بن

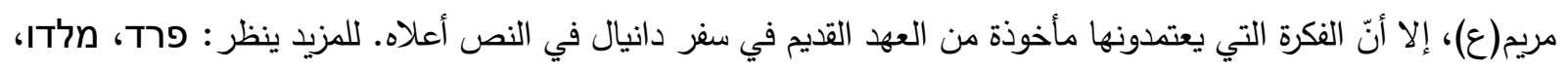

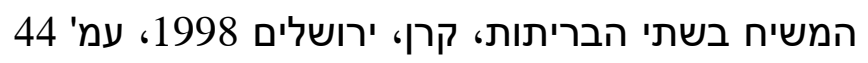




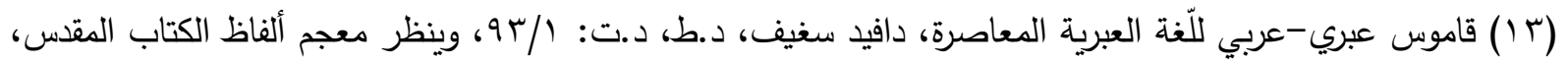

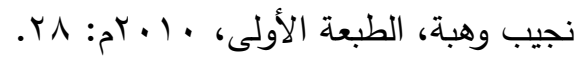

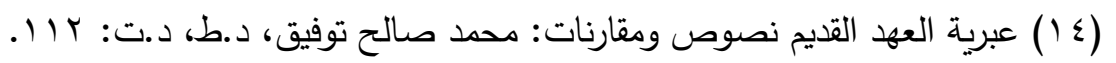

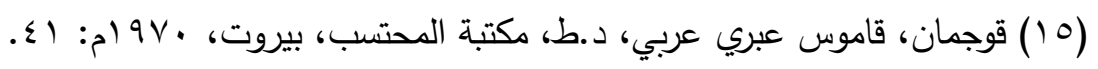

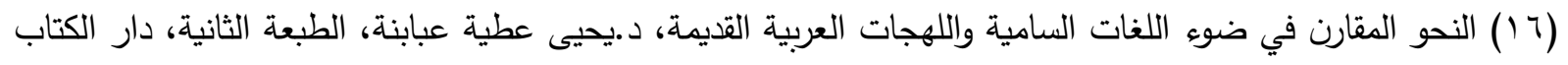

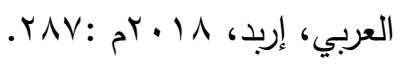

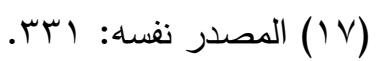
(1) (1) نظام الجملة في اللغات السامية الأكدية والأوغارتية والعبرية، سحر لطيف عقاد، أطروحة، جامعة حلب، كلية الآداب

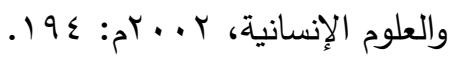

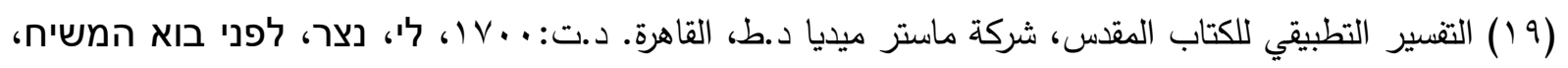
ספרית פועלים، ירושלים 1990، עמ' 129.

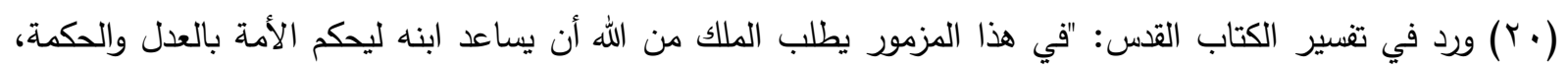

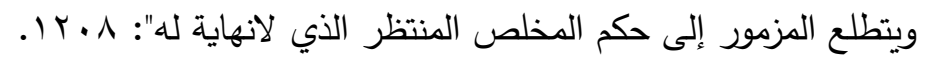

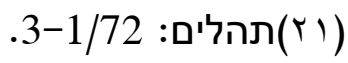
(Yr)

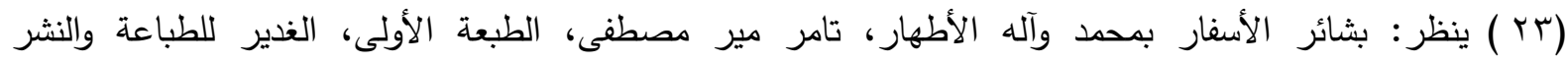

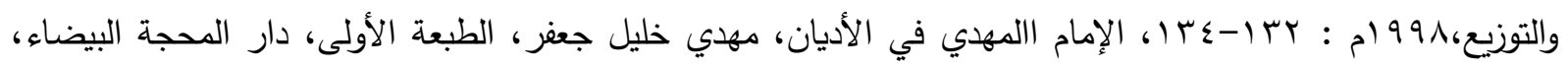

$$
\begin{aligned}
& \text {.VA-VO: } \\
& \text { (Y) }
\end{aligned}
$$

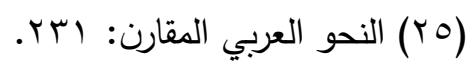

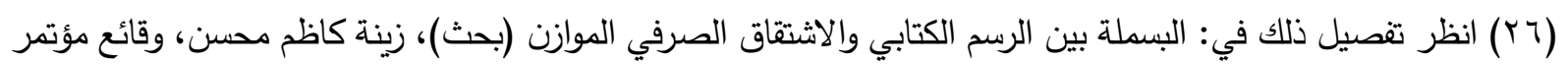

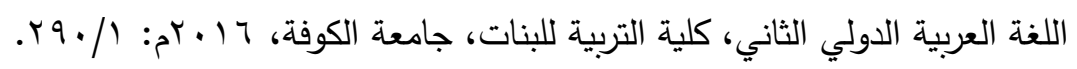

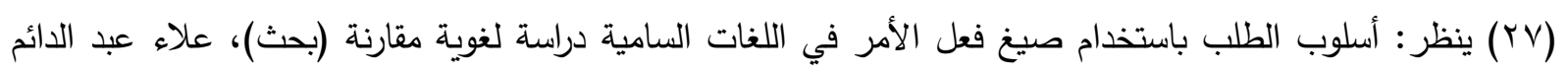




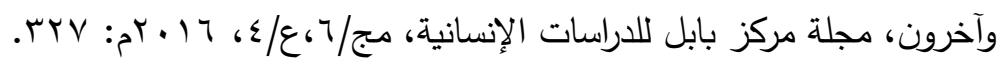

9/9: (ץ^)

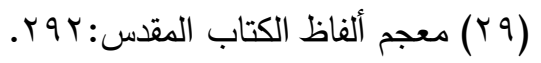

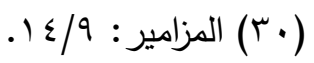

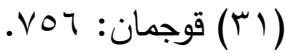

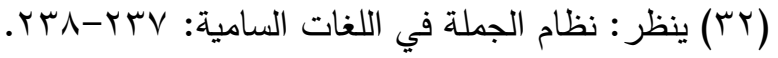

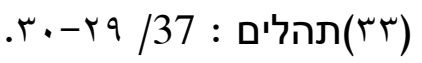

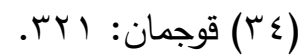

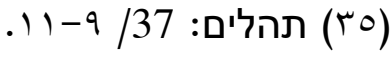

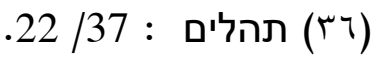

(11/10. (rv)

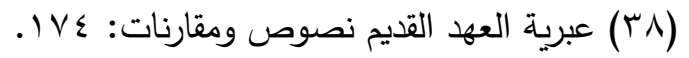

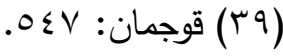

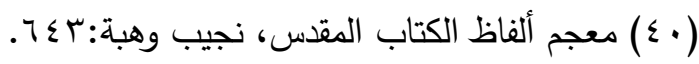

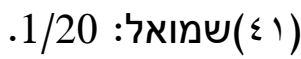

(ץミ) يمتاز الاسم عن الفعل بكونه يقبل:(الجر والتتوين ودخول ال التعريف عليه والإسناد): ينظر : شرح ابن عقيل على

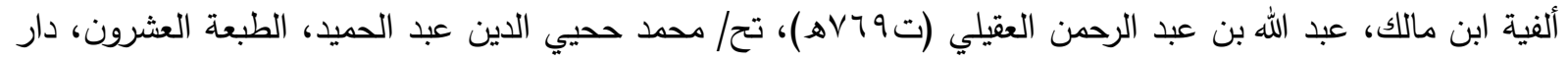

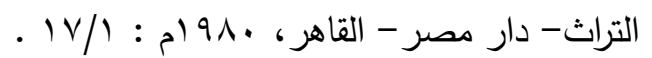

(بـ) راجع تفصيل المسألة في : الثعر في العهد القديم السمات والأغراض الفنية، سعيد عطية علي مطاوع: عـ، الثورات في أسفار العهد القديم بين الحقيقة والإدعاء، (رسالة ماجستير)، حمدي قر الدولة السيد خطاب، جامعة الأزهر، كلية أصول

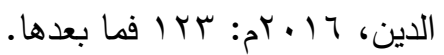

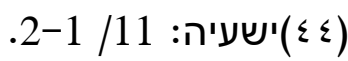

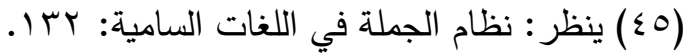

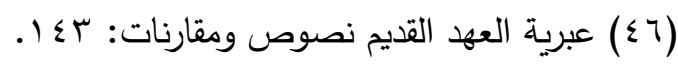




$$
\begin{aligned}
& \text { 32/37 : }
\end{aligned}
$$

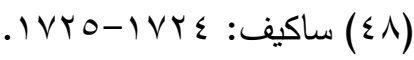

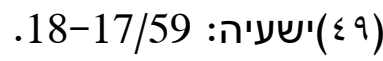

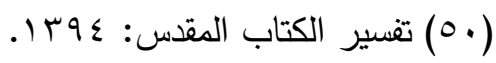

$$
\begin{aligned}
& \text { المصادر والمراجع: } \\
& \text { القرآن الكريح. } \\
& \text { الكتاب المقدس. }
\end{aligned}
$$

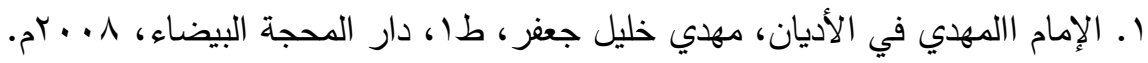

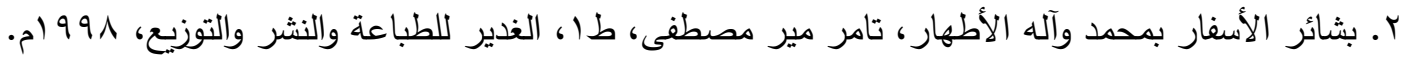

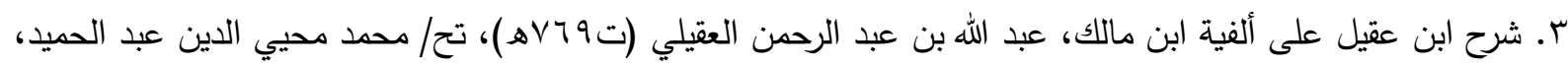
ط.r، دار التراث- دار مصر - القاهرة، •919 ام. ء. الثعر في العهد القديم السمات والأغراض الفنية، سعيد عطية علي مطاوع، مركز الدراسات الثرقية، جامعة القاهرة،

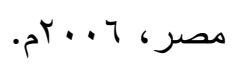

0. عبرية العهد القديم نصوص ومقارنات، محمد صالح توفيق، د.ط، د.ت.

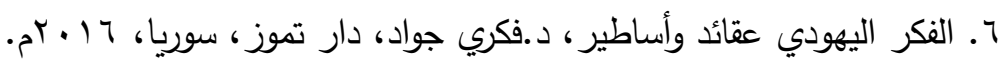

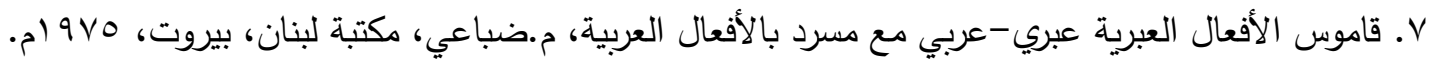

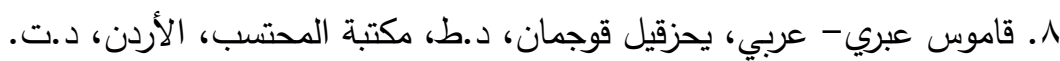

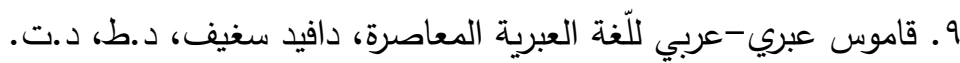

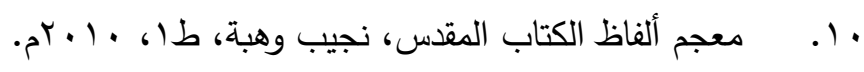

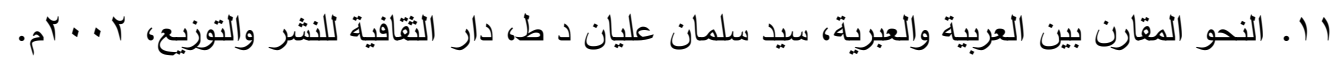

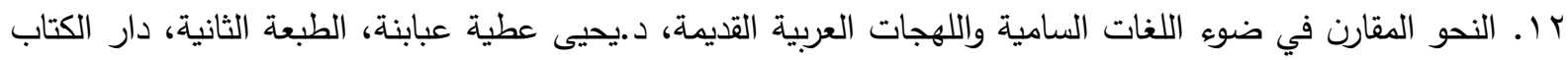

$$
\text { الرسائل والأطاريح، إربد، } 1 \text { • بم. }
$$

ا. الثورات في أسفار العها القديم بين الحقيقة والادعاء، رسالة ماجتير، حمدي قمر الدولة السيد خطاب، جامعة 
الأزهر، كلية الأصول الدين 17 إبم.

r. ـ نظام الجملة في اللغات السامية الأكدية والأوغارتية والعبرية، سحر لطيف عقاد، أطروحة، جامعة حلب ، كلية الآداب

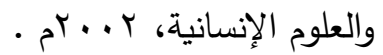

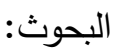
r. أسلوب الطلب باستخدام صيخ فعل الأمر في اللغات السامية ، دراسة لغوية مقارنه(بحث) علاء عبد الدائم وآخرون، مجلة مركز بابل للدراسات الإنسانية، 17 • بم.

ع. البسملة بين الرسم الكتابي والاشتقاق الصرفي الموزان (بحث)، زينة كاظم محسن، وقائع مؤتمر اللغة العربية الدولي

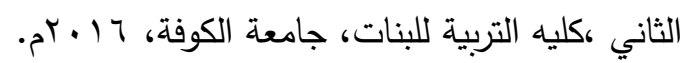

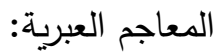
0. שגיב، דוד. מילון עברי ערבי לשפה עברית בת זמננו. כרך ראשון. 1985. ירושלים. עמ' 1090. צ. V. אברהם، אבן-שושן، המלון החדש، הוצאת קרית-ספר، ירושלים 1974. المصادر والمراجع العبرية: ^. רשתו שנתלה، המשיח בתנך، הוצאת קרן، ירושלים 2000. 9. לי، נצר، לפני בוא המשיח، ספרית פועלים، ירושלים 1990. • • י. פרד، מלדו، המשיח בשתי הבריתות، קרן، ירושלים 1998. - מנחים، שנרסון، שערי גאולי، הבד ירושלים 1991. ו. אברהם، גרליצקי، ימות המשיח בהלכה، עם עובד، ירושלים 2005. 
